\title{
Resignation of officials as independent directors and firm performance
}

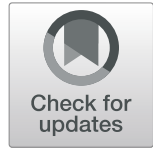

Ting Ren ${ }^{1^{*}}$ D, Youzhi Xiao ${ }^{1}$, Xinguo Yu ${ }^{1}$, Hongyan Yang ${ }^{2}$ and Jianmei $\mathrm{Ge}^{3}$

\author{
* Correspondence: renting@phbs. \\ pku.edu.cn \\ ${ }^{1}$ HSBC Business School, Peking \\ University, Shenzhen, China \\ Full list of author information is \\ available at the end of the article
}

\section{Springer Open}

\begin{abstract}
In 2013, the Chinese government implemented Rule No. 18, which suspended the directorships of incumbent government officials and precluded those who retired within the past three years from serving as independent directors for listed firms. The surprise implementation of Rule No. 18 triggered a wave of resignations among official independent directors (OIDs). The event provided a unique opportunity to examine the impacts of the political connections of board members on firm performance. We applied a difference-in-difference technique to empirically investigate the effect of OID resignations on firm performance from the perspectives of resource dependence theory and social capital theory. The results indicate that the resignation of OIDs had a significantly negative effect on firm performance, as measured by Tobin's $Q$ and firm leverage. This also confirmed the importance of independent directors' political connection on firm performance, as discovered in prior research. However, this influence varied across OIDs' heterogeneity, external environment and firm ownership. The results indicate that political connections may not be necessary channels for firms to achieve success.
\end{abstract}

Keywords: Firm performance, Independent director, Political connection, Resource dependence theory, Social capital theory

\section{Introduction}

Since the introduction of the role of independent director in listed companies in the 1990s, there have been considerable studies of this issue in China. Evidence from developed economies, such as the United Kingdom and the United States, has shown that independent directors can improve firm governance and performance through supervision and consulting functions (Faleye et al. 2011). Independent directors can help to reduce agency costs when they are truly independent because they are less susceptible to agency problems (Liu et al. 2015; Shivdasani and Yermack 1999; Weisbach 1988). A high proportion of independent directors in the board may reduce the efficiency of firm governance (Lefort and Urzúa 2008); however, the reputation of the independent directors may exert a significant positive impact on firm performance (Jiang et al. 2016). According to resource dependence theory (RDT) and social capital theory (SCT), the influence of independent directors on firm performance is associated with their human and social capitals (Chen et al. 2016; Dunn et al. 1986; Easterbrook 1984;

(c) The Author(s). 2020 Open Access This article is licensed under a Creative Commons Attribution 4.0 International License, which permits use, sharing, adaptation, distribution and reproduction in any medium or format, as long as you give appropriate credit to the original author(s) and the source, provide a link to the Creative Commons licence, and indicate if changes were made. The images or other third party material in this article are included in the article's Creative Commons licence, unless indicated otherwise in a credit line to the material. If material is not included in the article's Creative Commons licence and your intended use is not permitted by statutory regulation or exceeds the permitted use, you will need to obtain permission directly from the copyright holder. To view a copy of this licence, visit http://creativecommons.org/licenses/by/4.0/. 
Kim 2007; Kor and Sundaramurthy 2009; Liu et al. 2013; Nguyen and Nielsen 2010; Peng 2004; Tian et al. 2011). In transition economies such as China, the government has a strong influence on firm operations and political connections are considered valuable resources (Hu et al. 2020). It is common practice for listed firms to hire former or incumbent government officials as independent directors in order to cultivate and establish a relationship with the government (Faccio 2010).

The importance of an independent director's political connection for firm performance remains unresolved due to the difficulty of accounting for endogeneity in prior examinations, and because the selection of independent directors can hardly be exogenous (Harris and Raviv 2008; Hermalin and Weisbach 2001; Shivdasani and Yermack 1999). For example, Agrawal and Knoeber (2001) study the relationship between politically connected directors and firm value; however, the endogeneity issue is not fully considered in their study and may have caused endogenous bias. Kim (2007) studies the relationship between outside directors and firm performance and uses an instrumental variable approach to alleviate the endogenous bias; nonetheless, the possibility of reverse causation and quality signaling could not be completely ruled out. Therefore, solving the endogenous bias has become the main empirical challenge to studying the effects of official independent directors (OIDs) on firm performance (Cheng and Sun 2019; Li and Cheng 2020; Zhang et al. 2017). The implementation of the Chinese government's mandate on October 19, 2013, i.e., Rule No. 18, which banned incumbent government officials and those who have retired within the previous 3 years from serving as independent directors for listed firms, allows us to treat the policy as an exogenous shock to examine how OIDs exert their influence on firm performance through their political connections. Specifically, we use the exogenous regulatory shock as a quasi-natural experiment in which the OIDs were forced to resign from the listed firms. The firms' potential loss of their political connections as a result of the shock can then be analyzed to identify and confirm the causal relationship between OIDs and firm performance through the difference-in-difference (DID) technique. From the perspectives of RDT and SCT, we investigate the effect of OIDs on firm performance in an exogenous-shock setting, i.e., the effect of loss of a political resource by OID resignations. Moreover, we consider the varied effects of OID resignations in terms of differences in political hierarchy, tenure, serving state and professional background, as well as the impact of the external environment and the firms' internal political network on firm performance.

Unlike the supervisory function of independent directors (Chizema et al. 2015; Wang 2015), RDT and SCT emphasize that OIDs are endowed with political resources, which can bring crucial advantages to the firm (Fan et al. 2007; Li and Cheng 2020; Liu et al. 2013). Among the most relevant literature regarding the impact of Rule No. 18 is the paper by $\mathrm{Xu}$ (2018), who examines the effect of Rule No. 18 on firm value from the anti-corruption perspective. In contrast, we investigate the issue from the resources perspective, relying on RDT and SCT. We contribute to the extant literature in the following three aspects: Firstly, the value of OIDs on firm performance is investigated in an exogenous-shock setting, which can help to address the endogeneity problem inherent in some prior research. Secondly, considering that OIDs with different backgrounds will bring different resources and social capital, and in order to fully understand the role of OIDs, the heterogeneity of OIDs is studied in more depth, extending and 
supplementing the prior literature (Agrawal and Knoeber 1996; Cheng and Sun 2019; Hillman 2005; Tang et al. 2016; Xu 2018). Thirdly, compared with Lester et al. (2008) and $\mathrm{Hu}$ et al. (2020), considering that the resources and social capital brought by OIDs may play a different role under a different internal structures and external institutional environments, the moderating effects of firms' ownership and institutional environment are studied, which can offer deeper insights of these elements from the perspectives of RDT and SCT.

The remainder of the paper proceeds as follows: Section 2 introduces theories and develops hypotheses. Section 3 presents the data and the empirical methodology. Section 4 reports empirical results and robustness checks. Section 5 extends the discussions with some additional tests. Section 6 summarizes and concludes the paper.

\section{Theories and hypotheses}

In 2001, the China Securities Regulatory Commission (CSRC) mandated that no less than one-third of listed companies' boards should be independent directors. However, due to the fact that independent directors in China's listed companies are nominated and selected by controlling shareholders, there is no guarantee that they will be independent or fulfill the anticipated monitoring role (Clarke 2006; Jiang and Kim 2015). Independent directors are likely to be selected by the company for the resources and benefits that they are endowed with (Lester et al. 2008). Therefore, the theories of RDT (Pfeffer and Salancik 1978) and SCT (Adler and Kwon 2002) are appropriate to fully understand the role of OIDs from the perspectives of resources and social capital.

Given the importance of independent directors to listed firms, their voluntary resignations, likely associated with reputation concerns (Dewally and Peck 2010), will inevitably be perceived as a negative message by the market, with a potentially negative impact on stock price, corporate governance, and firm value (Huang and Chan 2018). The implementation of Rule No. 18 triggered a wave of OID resignations among Chinese listed firms. Firms experiencing the mandatory OID resignations suffered a sudden loss of political connections. As such, any change of the status related to access to loans or preferential taxation was likely to be associated with the loss of OIDs (Hu et al. 2020).

The issuance of Rule No. 18 as an external regulatory shock provided an opportunity to explicitly examine the value of political connections embedded within the OIDs. Thus far, research results are mixed in respect of the different aspects of investigation. Han and Zhang (2018) investigate that the announcements of OIDs' resignations generated significantly positive abnormal returns. $\mathrm{Xu}$ (2018) finds that the regulation reduced the value of firms with banned OIDs. Cheng and Sun (2019) find that the stock price of listed firms dropped an average of $4.61 \%$ in ten trading days after mandated OIDs' resignations. Qin and Zhang (2019) observe that the loss of political connection from OIDs' resignations significantly promoted innovation within the firms. Hu et al. (2020) show that the OIDs' resignations reduced firms' access to long-term bank loans and government subsidies. Wei et al. (2020) find out that the disruption of political connection following OIDs' resignations significantly increased the labor cost of the listed firms. Hope et al. (2020) find that Rule No. 18 effectively weakened the political connection and significantly improved the financial reporting quality of the firms. 
According to RDT and SCT, independent directors bring external resources to help create firm value (Peng 2004). Compared with non-official independent directors, OIDs are apparently more salient in owning political connections and better able to secure political resources for the firm. They can connect the firm to the government through their unique social capital (Liu et al. 2015). Therefore, firms with OIDs are more likely to receive preferential treatment, lighter taxation, better chances of getting government contracts, more relaxed regulatory oversight, and easier entry into high-barrier markets (Faccio 2006; Fisman 2001; Wang and Lin 2017).

RDT suggests that firms will make efforts to reduce their dependence on the external environment (Pfeffer and Salancik 1978). SCT suggests that social capital is a resource that is acquired from a firm's social network (Jensen and Murphy 1990). The combined predictions of RDT and SCT suggest that firms may exchange one form of capital to obtain another, using their government and social network to secure capital resources to reduce their dependence on the government (Adhikari et al. 2006; Boeker and Goodstein 1991; Farashahi and Hafsi 2009). Especially in a transitional economy, firms prefer to make use of social networks or social capital to acquire external resources (Peng and Heath 1996). When OIDs resigned, firms lost the political networks and capital brought by the OIDs, which made it harder for the firms to get external resources; therefore, the uncertainty faced by the firms may have increased. Consequentially, firm performance may be negatively affected by OID resignations.

\section{Hypothesis 1: The OID resignations negatively affect firm performance.}

OIDs come from different levels of the political hierarchy. The breadth and depth of OIDs' human and social capitals are determined by their positions within the political hierarchy (Lester et al. 2008). From the perspective of SCT, the higher an OID's level in the hierarchy, the greater the political power and the more political resources and social capital the OID can secure for the firm (Johnson and Mitton 2003). However, from the perspective of political distance, the central government is more remote from the listed firms, while the local government is closer and more relevant. Prior research has found that, compared to centrally related political connections, locally bound political connections are of more immediate benefit to the firms, since important factors such as administrative licensing, tax preference, and, crucially, local protection are all controlled by the local government (Infante and Piazza 2014; Shin and Ha 1999; Zhu et al. 2016). As such, although higher positions in the hierarchy may mean more resources, firms may not be able to readily leverage these connections due to the distance between the firm and the political hierarchy. Therefore, the effect of OIDs with local political connections may be more evident than counterparts with central political connections.

Hypothesis 2a: The resignation of OIDs with provincial or municipal official positions has a greater impact on firm performance than the resignation of OIDs with official positions at other hierarchical levels.

According to the Guidelines for Introducing Independent Directors to the Board of Directors of Listed Companies issued by the CSRC, independent directors should serve no more than two terms, or 6 years in total. The aim of the regulation is to maintain the 
effectiveness of independent directors. The importance of OIDs' tenure is twofold. On the one hand, according to Hillman et al. (2008), who applied the identity theory to study the role of independent directors, the longer the tenure that independent directors serve, the stronger their sense of identification with the organization. Directors who identify more strongly with an organization are more likely to spend their efforts (Dutton et al. 1994) and secure more resources for the firm (Hillman et al. 2008).

On the other hand, longer tenure helps OIDs develop better knowledge of the firm and offer more effective supervision and advice (Kim 2007; Reguera-Alvarado and Bravo 2017). However, longer tenure may have the opposite effect if the independent directors are assimilated by the firm's main stakeholders, which leads to higher tolerance of the firm's abnormal operations and a negative impact on the effectiveness of independent directors (Chen and Xiang 2017). Considering the combined advantages and disadvantages of OIDs' tenure, the effect on firm performance can vary. Nonetheless, the effect tends to be more evident with longer tenure.

Hypothesis 2b: The resignation of OIDs with longer tenure has a stronger impact on firm performance.

Serving status affects the capacity of independent directors to mobilize external resources. Those who have more political resources will provide more valuable information and resources to help the firm develop. Firms apparently prefer incumbent OIDs to retired officials and the likelihood of appointment to an independent directorship diminishes as retirement progresses (Lester et al. 2008). When a serving official is appointed as an independent director, he/she is more conveniently placed to bring political resources to the firm, while retired officials have a reduced ability to secure resources. Therefore, the resignation of OIDs with current or previous political positions makes a difference in its effect on firm performance.

Hypothesis 2c: The resignation of OIDs who are incumbent officials has a stronger impact on firm performance than that of OIDs who are retired officials.

OIDs' backgrounds indicate the quality of their human capital. Independent directors' industry-specific experience such as investment banking, law and finance can significantly influence firm behavior (Chen et al. 2016; Krishnan et al. 2011; Wang et al. 2015). Independent directors' academic background significantly improves firm performance, governance and innovation, alleviates information asymmetry, and reduces financing cost (Quan and Li 2017). OIDs' diverse human capital implies that they can bring diverse, valuable external information and expertise to link the organization to the external environment (Kim 2007). Therefore, the attraction of OIDs with different backgrounds derives from the need to secure a combination of human capital and social capital (Lester et al. 2008). The resignation of OIDs with valuable backgrounds such as industry-specific experience and academic expertise will inevitably influence firm performance.

Hypothesis 3a: The resignation of OIDs with different industry-specific backgrounds has different influences on firm performance. 
Hypothesis 3b: The resignation of OIDs with academic backgrounds negatively influences firm performance.

Firms need to devise effective strategies to minimize the uncertainty of the external environment that is vital to its development (Keim and Zeithaml 1986). One of the important roles that independent directors play is to link the organization with the external environment to obtain valuable resources (Kim 2007). Firms may appoint politically connected directors to reduce environmental uncertainty. The quality of the market and legal environment, as types of formal institutions, will influence firm behavior (Peng 2004). The need for firms to appoint OIDs for the purposes of extracting political resources from the outside environment to balance the market uncertainty therefore diminishes in areas with more developed market environments.

Hypothesis 4a: The higher the level of marketization of the region, the less impact the OID resignations have on firm performance.

The culture of guanxi is a prominent social phenomenon in China, which can be considered as a kind of informal institution. Together with formal institutions, i.e., marketization and legal protection, informal institutions also have an impact on economic behaviors (Puffer et al. 2010), especially in a transition economy. Guanxi has a significant impact on establishing political connections and generating better firm performance Luo and Chen 1997). In a region with stronger guanxi culture, firms may be more eager to establish political connections and the OIDs may play a more important role in corporate governance. Therefore, the OID resignations may have a greater effect on firm performance in areas with stronger guanxi culture.

Hypothesis 4b: The higher the level of guanxi, the stronger the impact of OID resignations on firm performance.

The ability to obtain political resources differs between state-owned enterprises (SOEs) and privately-held enterprises (non-SOEs). The studies of OIDs mostly concentrate on non-SOEs and the relationship between OIDs and corporate governance is not quite clear in the comparison between SOEs and non-SOEs (Cheng 2018; Hou et al. 2017; Shi et al. 2018; Tang et al. 2016; Wang 2015). On the one hand, firms have the incentive to appoint OIDs for the purpose of gaining more resources to help their development. Since the SOEs already have close links with the government, the sudden and mandatory resignation of OIDs may only inflict a limited shock on firm performance. On the other hand, OIDs may represent the interests of the government as the controlling shareholder of SOEs; therefore, they may be more motivated to pursue political goals that may undermine firm value (Wang 2015). Considering the loss of political connections associated with OID resignations, the non-SOEs will be more inclined to re-establish other connections to alleviate the impact of the sudden loss (He et al. 2017). By comparison, SOEs may not be eager to re-establish the political connections due to their connection with the government. Therefore, the OID resignations will have a stronger effect on non-SOEs than on SOEs. 
Hypothesis 4c: The OID resignations have a greater impact on firm performance in nonSOEs than in SOEs.

In summary, the research framework can be described as the following: Firstly, we investigate the direct effect of OID resignations on firm performance. Secondly, we study the heterogeneous characteristics of OIDs on firm performance, including political hierarchy, tenure, serving status, industry-specific background and academic background, which provide a comprehensive understanding of the effect of OID resignations. Thirdly, we study the moderating effects of the institutional environment, including the formal (i.e., marketization) and informal (i.e., guanxi) types, and firm ownership (i.e., SOEs vs. non-SOEs). Lastly, we discuss the phenomenon of the delay of OID resignations and some potential influencing channels.

\section{Method}

Data

We aim to examine the role of OIDs in firms by observing the resignations following the implementation of Rule No. 18 and its impact on firm performance. We use data of all A-share listed firms on the Shanghai and Shenzhen Stock Exchanges from 2009 to 2017, excluding financially distressed firms and firms in the financial sector. We handcollect data from public websites and listed company databases including SINA Finance, CNINFO and the WIND database for independent directors' resignations and biographic information. The financial and corporate governance data of the firm are obtained from the China Stock Market \& Accounting Research (CSMAR) database and the WIND database. The marketization index is from China's Provinces Marketization Index Report (Wang et al. 2018). The guanxi index is from Ye et al. (2016).

The data collection and cleaning process is as follows: First, we collect all firm announcements on independent directors' resignations released between October 19, 2013, the effective date of Rule No. 18, and December 31, 2015, in order to eliminate possible interference from other factors. Secondly, we review independent directors' biographies to evaluate the status of their political connection. In line with prior literature (Fan et al. 2007; Hu et al. 2020; Lin et al. 2012), OIDs are defined as either (1) officials of the central or local governments and financial regulatory bodies; (2) representatives of People's Congress at various levels; and (3) members of the Committee of the Chinese People's Political Consultative Conference at various levels. The political hierarchy, serving status, professional background and tenure of independent directors are also obtained. The total sample consists of 3,265 firms and includes 781 firms with OIDs who resigned between 2013 and 2015 as the treatment group, and the remaining balance of 2,484 firms that did not have OID resignations as the control group.

\section{Variable}

\section{Dependent variable}

The dependent variable is firm performance. We apply three indicators of financial profitability, namely $R O A, R O E$ and Tobin's $Q$, to measure firm performance, and financial leverage $(L E V)$ to measure firm risk. $R O A$ refers to the total return on assets, which 
measures how much net profit a unit of asset creates. It is a comprehensive indicator of the firm's profitability. $R O E$ refers to the ratio of profit to equity, which represents the net return on stockholders' equity. Tobin's $Q$ refers to the ratio of the market value of the firm to the replacement value, indicating whether the firm is overvalued. The replacement cost is determined by the book value of firm assets. $L E V$ is measured as the ratio of earnings before interest and taxes (EBIT) to fixed financing cost.

\section{Independent variable}

Considering the nature of the resignation event, we adopt the DID technique for the empirical analysis. We generate the interaction term Treat $\times$ Post for the examination. Specifically, Post is a binary indicator of the state before or after the resignation event, which equals 1 for the time after an announcement of resignation, and 0 before the announcement. Treat is a binary variable used to identify the treatment group and the control group. Within the treatment group, the variable Treat is further classified according to political hierarchy of OIDs, serving status, tenure of OIDs and academic and professional background of OIDs.

The political hierarchy of OIDs is determined according to their position. A value of 1 is recorded in one of five levels to indicate whether the official is at central (Level1), provincial (Level2), municipal (Level3), county (Level4), or other of government (Level5), respectively, with all other values remaining 0. When the CSMAR has multiple level assignments for an individual, it is recorded at the highest level. For serving status, if the OIDs are incumbent officials, the variable Present equals 1; if the OIDs are retired officials, the variable Previous equals 1 , with all other values remaining 0 . The tenure of OIDs is calculated as the time difference between the date when the official began to serve as an independent director and the date when the firm issued a resignation announcement. According to Guidelines for Introducing Independent Directors to the Board of Directors of Listed Companies issued by the CSRC, independent directors shall not serve more than two terms, or 6 years in total. However, in the data set of the present study, among the total of 1,163 OIDs, there are 116 OIDs who served more than 6 years, and the longest tenure recorded was 14 years. Therefore, in order to test the heterogeneous influence of OIDs' tenure, we generate a few binary variables: If the tenure is within one term or 3 years, then Tenure 1 equals 1 ; if the tenure is within two terms or 6 years, then Tenure 2 equals 1 ; if the tenure is more than two terms or 6 years, then Tenure 3 equals 1, with all other values remaining 0 . For academic and professional background of OIDs, if the OIDs have experience in college, a scientific research institution or related associations, the variable Academic equals 1, 0 otherwise. For the professional background, we generate three binary variables to indicate working experience in respective areas that are important to firm operation: If the OIDs have working experience in human resource, management and marketing, Pro1 equals 1; if the OIDs have working experience in R\&D, manufacturing and designing, Pro2 equals 1; if the OIDs have working experience in finance and law, Pro3 equals 1, with all other values remaining 0.

\section{Moderating variable}

For the marketization level (MrktIndex) of the region where the firm is located, we use the marketization index and the sub-index of marketization of finance (Fin) and law 
environment (Law) from Wang et al. (2018). The index of guanxi of the region where the firm is located is used as a proxy for the quality of the informal institution from Ye et al. (2016), which calculate the guanxi index of the provinces in China from 2000 to 2010. In order to match the time scale with the corporate data from 2009 to 2017, we use the average of the guanxi index of 2008 and 2010 as the measure for 2009, and use the guanxi index of 2010 as the measure for 2010-2017. The variable Ownership indicates the type of actual control of the firm, a binary value which equals 1 for SOEs, and 0 for non-SOEs.

\section{Control variable}

A number of control variables are included to avoid the omitted variable bias. These variables are based on the work of $\mathrm{Hu}$ et al. (2020), Cheng and Sun (2019) and Li et al. (2008). They include: the log form of total assets (Lnasset), firm age (Lnfirmage), equity to debt ratio $(E / D)$, proportion of independent directors in the board (InDir), sales growth rate $(S G R), \log$ form of board size (LnDirector), fixed asset ratio (PPE), CEOchairman duality (Duality), percentage of the largest shareholding (Largest) and the Herfindahl-Hirschman Index of the operating income of the ten largest firms compared to the total operating income of the industry (Herfindahl). Together, these variables are used to describe the shareholding, asset, capital, and governance structures as well as the growth potential, industry competition and other features of the firm. Table 1 shows the mean, standard deviation and correlation of each of these variables.

\section{Empirical strategy}

We employed the DID technique to test the hypotheses, using the following baseline equation:

$$
y_{i, t}=\beta_{0}+\beta_{1} \text { Treat }_{i} \times \text { Post }_{t}+\Sigma \Sigma \beta_{i, t} X_{i, t}+\mu_{i}+\eta_{t}+\varepsilon_{i, t} .
$$

$y_{i, t}$ is a group of variables indicating firm performance, including $R O E, R O A$, Tobin's $Q$ and $L E V$. Treat $_{i}=1$ if OID resignations occurred after the implementation of Rule No. 18. Post $_{t}=1$ for the time after the announcement of OID resignations. $X_{i, t}$ is a vector of control variables. $\mu_{i}$ is the firm fixed effect. $\eta_{t}$ is the time fixed effect.

\section{Result}

\section{The influence of OID resignations}

In order to apply the DID approach to test the relationship between OID resignations and firm performance, the parallel trend assumption should first be tested. The results of the parallel trend test show that both Tobin's $Q$ and $L E V$ satisfy the parallel trend assumption while $R O A$ and $R O E$ do not; therefore, the PSM-DID approach is used in the robustness check (Imbens 2015).

We use the DID approach to test the baseline hypothesis, i.e., the influence of Rule No. 18 on firm performance, using the two-way fixed effect model. The results of Table 2 show that the coefficient of Treat $\times$ Post for Tobin's $Q$ is significantly negative, indicating that the OID resignations have a negative influence on Tobin's $Q$. However, the coefficients of Treat $\times$ Post for $R O E$ and $R O A$ are not significant, suggesting that the loss of political connections may influence the market value of the firm, but the firm's profitability may not be affected. In addition, the coefficient of Treat $\times$ Post for $L E V$ is 


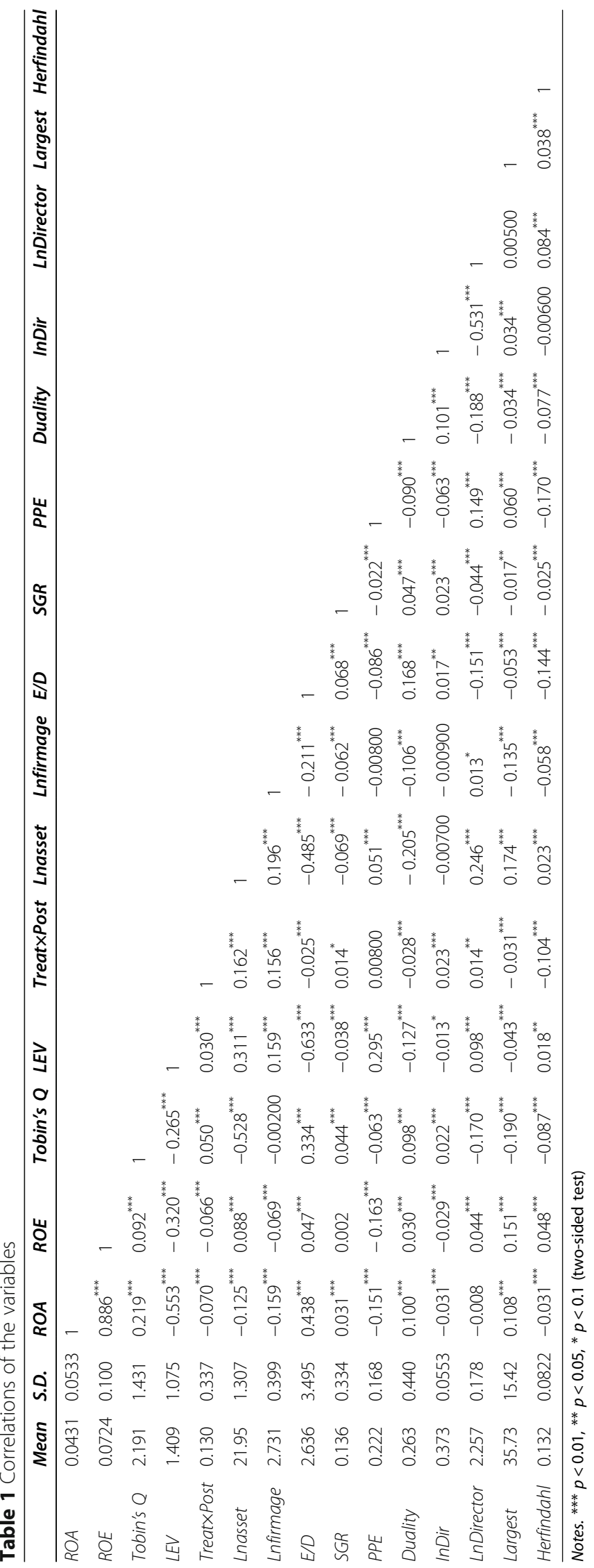


Table 2 Results of DID strategy

\begin{tabular}{|c|c|c|c|c|}
\hline & (1) & $(2)$ & (3) & (4) \\
\hline & $R O A$ & $R O E$ & Tobin's $Q$ & LEV \\
\hline Treat×Post & $0.0005(0.0018)$ & $0.0005(0.0035)$ & $-0.1556^{* * *}(0.0438)$ & $0.1166^{* * *}(0.0377)$ \\
\hline Lnasset & $0.0022(0.0016)$ & $0.0066^{* *}(0.0032)$ & $-1.0720^{* * *}(0.0494)$ & $0.0386(0.0302)$ \\
\hline Lnfirmage & $-0.0216^{* * *}(0.0052)$ & $-0.0148(0.0097)$ & $1.0827^{* * *}(0.1345)$ & $0.1084(0.0984)$ \\
\hline$E / D$ & $0.0012^{* * *}(0.0003)$ & $-0.0012^{* * *}(0.0004)$ & $-0.0540^{* * *}(0.0067)$ & $-0.0312^{* * *}(0.0034)$ \\
\hline$S G R$ & $-0.0010(0.0010)$ & $-0.0015(0.0023)$ & $-0.0397^{*}(0.0209)$ & $0.0212(0.0226)$ \\
\hline$P P E$ & $-0.0694^{* * *}(0.0081)$ & $-0.1383^{* * *}(0.0167)$ & $-0.4029^{* *}(0.1758)$ & $1.3493^{* * *}(0.1607)$ \\
\hline Duality & $0.0022(0.0017)$ & $0.0037(0.0034)$ & $-0.0311(0.0372)$ & $-0.0176(0.0340)$ \\
\hline InDir & $-0.0014(0.0147)$ & $-0.0125(0.0311)$ & $0.8037^{* *}(0.3182)$ & $0.3114(0.3446)$ \\
\hline LnDirector & $0.0147^{* *}(0.0060)$ & $0.0222^{*}(0.0124)$ & $0.1420(0.1416)$ & $-0.0419(0.1167)$ \\
\hline Largest & $0.0008^{* * *}(0.0001)$ & $0.0016^{* * *}(0.0002)$ & $-0.0101^{* * *}(0.0023)$ & $-0.0074^{* * *}(0.0018)$ \\
\hline Herfindahl & $0.0112(0.0141)$ & $0.0137(0.0232)$ & $-2.0202^{* * *}(0.3940)$ & $0.5066^{* * *}(0.1748)$ \\
\hline Constant & $0.0029(0.0417)$ & $-0.0931(0.0849)$ & $22.9555^{* * *}(1.1704)$ & $0.2026(0.7720)$ \\
\hline Firm fixed effect & YES & YES & YES & YES \\
\hline Year fixed effect & YES & YES & YES & YES \\
\hline N & 18,942 & 18,798 & 18,026 & 17,444 \\
\hline Adj_R $R^{2}$ & 0.0754 & 0.0594 & 0.3539 & 0.0366 \\
\hline F & 38.1214 & 30.5470 & 139.0495 & 18.3673 \\
\hline
\end{tabular}

(1) Cluster robust standard errors at firm level are in parentheses; (2) ${ }^{* *} p<0.01,{ }^{* *} p<0.05,{ }^{*} p<0.1$ (two-sided test)

significantly positive, indicating that the OID resignations will significantly increase the leverage or risks of the firm. On the balance of these results, the OID resignations can exert certain negative influences on firm performance, such as reducing firm value and increasing leverage, but not much on firm profitability. Our findings therefore support Hypothesis 1, but only partially.

We use a group of variables to identify the influence of the OIDs' political connections at different levels of the political hierarchy on firm performance. We divide all the OIDs into five groups based on political hierarchy and interact these variables with Post. The results are shown in Table 3. For Tobin's Q, the coefficients of Level $\times$ Post and Level3 $\times$ Post are significantly negative, which indicates that the resignation of OIDs with provincial and municipal political backgrounds significantly decreases Tobin's $Q$ of the firm. For $R O A$, the coefficient of Level $2 \times$ Post is significantly positive, which indicates that the resignation of OIDs with provincial political background significantly improves the $R O A$ of the firm. For $R O E$, the coefficient of Level1 $\times$ Post is significantly positive, which indicates that the resignation of OIDs with central political background significantly improves the ROE of the firm. As for LEV, the coefficients of Level $\times$ Post, Level $3 \times$ Post and Level4 $\times$ Post are all significantly positive, which indicate that the resignation of OIDs with provincial, municipal and county political backgrounds significantly increases the leverage or risks of the firm. On the balance of these results, we find that the resignation of OIDs in different hierarchical levels generates diverse impacts on firm performance, such as increasing the profitability ( $R O A$ and $R O E$ ) and risks (LEV) while reducing the firm value (Tobin's $Q$ ). This suggests a potential trade-off between levels of political hierarchy, which is associated with the amount of resources that an OID can render, and political distance that is associated with agency cost. Therefore, we find mixed but meaningful evidence to confirm Hypothesis 2a. 
Table 3 Influence of different administrative levels

\begin{tabular}{lllll}
\hline & $\mathbf{( 1 )}$ & $\mathbf{( 2 )}$ & $\mathbf{( 3 )}$ & $\mathbf{( 4 )}$ \\
& $\mathbf{R O A}$ & $\mathbf{R O E}$ & Tobin's $\mathbf{Q}$ & LEV \\
\hline Level1 $\times$ Post & $0.0071(0.0059)$ & $0.0225^{*}(0.0121)$ & $-0.0155(0.1462)$ & $-0.0872(0.1093)$ \\
Level $\times$ Post & $0.0075^{* *}(0.0036)$ & $0.0112(0.0074)$ & $-0.1705^{*}(0.0895)$ & $0.1248^{*}(0.0721)$ \\
Level3 $\times$ Post & $-0.0009(0.0025)$ & $-0.0035(0.0047)$ & $-0.2621^{* * *}(0.0641)$ & $0.1094^{*}(0.0569)$ \\
Level4 $\times$ Post & $-0.0026(0.0031)$ & $-0.0049(0.0067)$ & $-0.0687(0.0734)$ & $0.1693^{* *}(0.0679)$ \\
Level5 $\times$ Post & $-0.0042(0.0054)$ & $-0.0038(0.0104)$ & $0.0168(0.1261)$ & $0.0984(0.0984)$ \\
Control variable & YES & YES & YES & YES \\
Firm fixed effect & YES & YES & YES & YES \\
Year fixed effect & YES & YES & YES & YES \\
$N$ & 18,942 & 18,798 & 18,026 & 17,444 \\
Adj_R $R^{2}$ & 0.0761 & 0.0600 & 0.3545 & 0.0367 \\
$F$ & 32.4989 & 25.7171 & 115.0241 & 15.2755 \\
\hline
\end{tabular}

Notes.(1) Cluster robust standard errors at firm level are in parentheses; (2) ${ }^{* * *} p<0.01,{ }^{* *} p<0.05,{ }^{*} p<0.1$ (two-sided test)

Next, we consider the influence of the OIDs' tenure. We use a set of binary variables to identify OIDs' tenure and interacted them with Post. The results are shown in Table 4. For Tobin's $Q$, the coefficients of Tenure $1 \times$ Post, Tenure $2 \times$ Post and Tenure $3 \times$ Post are significantly negative, indicating that the different tenures of OIDs will have a significant impact on Tobin's $Q$. Further comparing the coefficients of Tenure $1 \times$ Post, Tenure $2 \times$ Post and Tenure $3 \times$ Post, we find that the coefficient of Tenure $3 \times$ Post is the largest, while the coefficient of Tenure $1 \times$ Post is the smallest, which indicates that longer tenure of the OIDs has a larger influence on firm performance. For $R O A$ and $R O E$, the coefficients of Tenure $3 \times$ Post are significantly positive, which indicates that the resignation of OIDs with longer tenure will positively influence the profitability of the firm. As for $L E V$, the coefficients of Tenure $1 \times$ Post and Tenure $2 \times$ Post are significantly positive and the coefficient of Tenure $1 \times$ Post is larger, indicating that the resignation of OIDs with shorter tenure increases the leverage of the firm. All of these results show that the effectiveness of OIDs increases as their tenure extends. Therefore, Hypothesis $2 \mathrm{~b}$ is mostly supported.

Table 4 Influence of tenure

\begin{tabular}{lllll}
\hline & $\mathbf{( 1 )}$ & $\mathbf{( 2 )}$ & $\mathbf{( 3 )}$ & $\mathbf{( 4 )}$ \\
& $\mathbf{R O A}$ & $\mathbf{R O E}$ & Tobin's $Q^{*}$ & LEV \\
\hline Tenure1 $\times$ Post & $-0.0006(0.0022)$ & $-0.0036(0.0044)$ & $-0.1208^{* *}(0.0591)$ & $0.1614^{* * *}(0.0543)$ \\
Tenure2 $\times$ Post & $-0.0011(0.0026)$ & $-0.0032(0.0053)$ & $-0.1339^{* *}(0.0668)$ & $0.0988^{* *}(0.0500)$ \\
Tenure3 $\times$ Post & $0.0099^{* *}(0.0046)$ & $0.0249^{* * *}(0.0092)$ & $-0.2968^{* * *}(0.0886)$ & $0.0271(0.0923)$ \\
Control variable & YES & YES & YES & YES \\
Firm fixed effect & YES & YES & YES & YES \\
Year fixed effect & YES & YES & YES & YES \\
$N$ & 18,942 & 18,798 & 18,026 & 17,444 \\
Adj_R $R^{2}$ & 0.0760 & 0.0605 & 0.3541 & 0.0367 \\
$F$ & 35.5552 & 28.4967 & 125.7621 & 16.8195 \\
\hline
\end{tabular}

Notes.(1) Cluster robust standard errors at firm level are in parentheses; (2) ${ }^{* * *} p<0.01, * * p<0.05, * p<0.1$ (two-sided test) 
As for the serving status of the OIDs, two binary variables, Previous and Present, are defined and interacted with Post. The coefficients of Previous $\times$ Post and Present $\times$ Post indicate the effect of the resignation of OIDs of different serving status. The results are shown in Table 5. The coefficients of Previous $\times$ Post and Present $\times$ Post for both Tobin's $Q$ and $L E V$ are significant, while the coefficients for Tobin's $Q$ are significantly negative and the coefficients for $L E V$ are positive. Comparing the coefficients of Previous $\times$ Post and Present $\times$ Post, we can see that the coefficient of Present $\times$ Post for both Tobin's $Q$ and $L E V$ is larger than that of Previous $\times$ Post, suggesting that the resignation of incumbent officials will have a stronger effect on firm performance than the resignation of retired officials. Therefore, Hypothesis $2 \mathrm{c}$ is supported.

Taking into account the academic and specific industry backgrounds of the OIDs, we interact the variables Academy and Pro1, Pro2 and Pro3, respectively, with Post. The results are shown in Tables 6 and 7. From the results of Table 6, we can see that the coefficient of AcademyxPost is significantly negative for Tobin's $Q$ and significantly positive for $L E V$, indicating that the resignation of OIDs with academic backgrounds will affect the firm performance. Comparing these coefficients with the results of Table 2 , the magnitudes are smaller. Therefore, the resignation of OIDs with academic backgrounds will affect the firm performance, but to a smaller degree. From the results of Table 7, we can see that, for Tobin's $Q$, the coefficients of Pro $1 \times$ Post and Pro $3 \times$ Post are significantly negative. The results show that the resignation of OIDs with management, law and finance backgrounds will significantly influence firm performance. As for $L E V$, only the coefficient of Pro3 $\times$ Post is significantly positive, which indicates that the resignation of OIDs with law and financial backgrounds will significantly influence firm leverage. In general, both Hypotheses $3 \mathrm{a}$ and $3 \mathrm{~b}$ are supported.

\section{The influence of the external environment and firm ownership}

We examine the effect of two kinds of external environment, namely formal and informal institutions, on the relationship between OID resignations and firm performance. For the formal institution, we test the influence of marketization, specifically the financial and legal environments. For the informal institution, we test the influence of guanxi culture. The interaction terms of Treat $\times$ Post $\times M K T$, Treat $\times$ Post $\times$ Fin, Treat $\times$ Post $\times$ Law and Treat $\times$ Post $\times$ Guanxi are defined and the results are shown in Tables 8

Table 5 Influence of serving status

\begin{tabular}{lllll}
\hline & $\mathbf{( 1 )}$ & $\mathbf{( 2 )}$ & $\mathbf{( 3 )}$ & $\mathbf{( 4 )}$ \\
& $\mathbf{R O A}$ & $\mathbf{R O E}$ & Tobin's $\mathbf{Q}$ & LEV \\
\hline PresentXPost & $-0.0032(0.0030)$ & $-0.0029(0.0061)$ & $-0.2260^{* * *}(0.0793)$ & $0.1173^{* *}(0.0585)$ \\
Previous $\times$ Post & $0.0021(0.0020)$ & $0.0022(0.0040)$ & $-0.1276^{* * *}(0.0488)$ & $0.1156^{* * *}(0.0439)$ \\
Control variable & YES & YES & YES & YES \\
Firm fixed effect & YES & YES & YES & YES \\
Year fixed effect & YES & YES & YES & YES \\
N & 18,942 & 18,798 & 18,026 & 17,444 \\
Adj_R $R^{2}$ & 0.0756 & 0.0594 & 0.3540 & 0.0365 \\
F & 36.3544 & 29.0245 & 132.4052 & 17.4480 \\
\hline
\end{tabular}

Notes.(1) Cluster robust standard errors at firm level are in parentheses; (2) ${ }^{* *} p<0.01,{ }^{* *} p<0.05,{ }^{*} p<0.1$ (two-sided test) 
Table 6 Influence of academic background

\begin{tabular}{lllll}
\hline & $\mathbf{( 1 )}$ & $\mathbf{( 2 )}$ & $\mathbf{( 3 )}$ & $\mathbf{( 4 )}$ \\
& $\boldsymbol{R O A}$ & $\mathbf{R O E}$ & Tobin's $\mathbf{Q}$ & LEV \\
\hline AcademyxPost & $-0.0005(0.0019)$ & $-0.0010(0.0038)$ & $-0.1508^{* * *}(0.0474)$ & $0.0984^{* *}(0.0414)$ \\
Control variable & YES & YES & YES & YES \\
Firm fixed effect & YES & YES & YES & YES \\
Year fixed effect & YES & YES & YES & YES \\
$N$ & 18,942 & 18,798 & 18,026 & 17,444 \\
Adj_R $R^{2}$ & 0.0754 & 0.0594 & 0.3537 & 0.0362 \\
$F$ & 38.0330 & 30.5166 & 138.9966 & 18.3155 \\
\hline
\end{tabular}

Notes.(1) Cluster robust standard errors at firm level are in parentheses; (2) ${ }^{* * *} p<0.01,{ }^{* *} p<0.05,{ }^{*} p<0.1$ (two-sided test)

and 9. From Panel A of Table 8 we can see that, for Tobin's $Q$, the interaction term of Treat $\times$ Post $\times M K T$ is significantly positive while, for $L E V$, the interaction term of Treat $\times$ Post $\times M K T$ is significantly negative, suggesting that marketization exerts a moderating effect on the impact of OID resignations on Tobin's $Q$ and $L E V$. Specifically, in regions with higher levels of marketization, the value of Tobin's $Q$ will decrease less, while the value of $L E V$ will increase, but only moderately. Panels B and C of Table 8 indicate that the financial marketization and legal environment will have a similar moderating effect as the general marketization index. From the results of Table 9, we can see that the interaction term of Treat $\times$ Post $\times$ Guanxi is significantly negative for Tobin's $Q$. This indicates that the culture of guanxi will have a negative moderating effect on Tobin's $Q$, and suggests that, in the regions with a stronger culture of guanxi, the OID resignations will cause a sharper decrease of Tobin's $Q$ than firms located in the regions with a weaker culture of guanxi. The moderating effects of formal institutions (i.e., marketization environment), and informal institutions (i.e., guanxi) are generally salient in the relationship between OID resignations and firm performance. Therefore, Hypothesis $4 \mathrm{a}$ and Hypothesis $4 \mathrm{~b}$ are supported.

As for the influence of firm ownership, the interaction term of Treat $\times$ Post $\times$ Ownership is used in the model. The results of Table 10 show that the coefficient of TreatxPost $\times$ Ownership is significantly negative for Tobin's $Q$ but significantly positive for $L E V$. The results indicate that, compared to non-SOEs, the resignation of OIDs in SOEs

Table 7 Influence of industry-specific background

\begin{tabular}{lllll}
\hline & $\mathbf{( 1 )}$ & $\mathbf{( 2 )}$ & $\mathbf{( 3 )}$ & $\mathbf{( 4 )}$ \\
& $\boldsymbol{R O A}$ & $\mathbf{R O E}$ & Tobin's $\mathbf{Q}^{*}$ & LEV \\
\hline Pro1 $\times$ Post & $0.0043(0.0037)$ & $0.0063(0.0080)$ & $-0.1953^{* *}(0.0851)$ & $0.1339(0.0866)$ \\
Pro2 $\times$ Post & $0.0015(0.0026)$ & $0.0086(0.0060)$ & $-0.0582(0.0871)$ & $0.1152(0.0716)$ \\
Pro3 $\times$ Post & $-0.0022(0.0023)$ & $-0.0059(0.0044)$ & $-0.2044^{* * *}(0.0541)$ & $0.1209^{* * * *}(0.0461)$ \\
Control variable & YES & YES & YES & YES \\
Firm fixed effect & YES & YES & YES & YES \\
Year fixed effect & YES & YES & YES & YES \\
N & 18,942 & 18,798 & 18,026 & 17,444 \\
Adj_R $R^{2}$ & 0.0756 & 0.0598 & 0.3543 & 0.0365 \\
F & 34.7835 & 27.9858 & 126.0632 & 16.6648 \\
\hline
\end{tabular}

Notes.(1) Cluster robust standard errors at firm level are in parentheses; (2) ${ }^{* * *} p<0.01,{ }^{* *} p<0.05, * p<0.1$ (two-sided test) 
Table 8 Influence of marketization

\begin{tabular}{|c|c|c|c|c|}
\hline & (1) & $(2)$ & (3) & (4) \\
\hline & $R O A$ & $R O E$ & Tobin's $Q$ & LEV \\
\hline \multicolumn{5}{|c|}{ Panel A Influence of marketization index } \\
\hline Treat $\times$ Post & $0.00004(0.0018)$ & $-0.0013(0.0038)$ & $-0.1848^{* * *}(0.0445)$ & $0.1370^{* * *}(0.0417)$ \\
\hline MKT & $0.0005(0.0012)$ & $-0.0001(0.0024)$ & $0.1001^{* * *}(0.0285)$ & $-0.0175(0.0275)$ \\
\hline Treat $\times$ Post $\times M K T$ & $0.0014(0.0009)$ & $0.0046^{* *}(0.0019)$ & $0.0881^{* * *}(0.0238)$ & $-0.0494^{* *}(0.0228)$ \\
\hline Control variable & YES & YES & YES & YES \\
\hline Firm fixed effect & YES & YES & YES & YES \\
\hline Year fixed effect & YES & YES & YES & YES \\
\hline N & 18,942 & 18,798 & 18,026 & 17,444 \\
\hline $\operatorname{Adj} \_R^{2}$ & 0.0756 & 0.0600 & 0.3568 & 0.0372 \\
\hline F & 34.5638 & 27.8058 & 127.7309 & 16.7583 \\
\hline \multicolumn{5}{|c|}{ Panel B Influence of financial environment } \\
\hline Treat $\times$ Post & $0.0005(0.0018)$ & $0.0003(0.0035)$ & $-0.1605^{* * *}(0.0436)$ & $0.1197^{* * *}(0.0381)$ \\
\hline Fin & $-0.0019^{* *}(0.0009)$ & $-0.0028(0.0017)$ & $-0.0347(0.0214)$ & $0.0529^{* * * *}(0.0204)$ \\
\hline Treat $\times$ Post $\times$ Fin & $0.0008(0.0008)$ & $0.0030^{* *}(0.0015)$ & $0.0789^{* * * *}(0.0201)$ & $-0.0456^{* *}(0.0177)$ \\
\hline Control variable & YES & YES & YES & YES \\
\hline Firm fixed effect & YES & YES & YES & YES \\
\hline Year fixed effect & YES & YES & YES & YES \\
\hline N & 18,942 & 18,798 & 18,026 & 17,444 \\
\hline $\operatorname{Adj} \_R^{2}$ & 0.0758 & 0.0598 & 0.3555 & 0.0377 \\
\hline F & 35.0720 & 27.8401 & 127.1825 & 16.7560 \\
\hline \multicolumn{5}{|c|}{ Panel C Influence of legal environment } \\
\hline Treat $\times$ Post & $0.0002(0.0018)$ & $-0.0006(0.0037)$ & $-0.1730^{* * *}(0.0441)$ & $0.1297^{* * *}(0.0403)$ \\
\hline Law & $-0.0002(0.0004)$ & $-0.0005(0.0008)$ & $0.0242^{* * *}(0.0093)$ & $0.0004(0.0087)$ \\
\hline Treat $\times$ Post $\times$ Law & $0.0004(0.0003)$ & $0.0014^{* *}(0.0007)$ & $0.0267^{* * *}(0.0083)$ & $-0.0150^{*}(0.0078)$ \\
\hline Control variable & YES & YES & YES & YES \\
\hline Firm fixed effect & YES & YES & YES & YES \\
\hline Year fixed effect & YES & YES & YES & YES \\
\hline N & 18,942 & 18,798 & 18,026 & 17,444 \\
\hline Adj_R $R^{2}$ & 0.0755 & 0.0597 & 0.3558 & 0.0369 \\
\hline F & 34.5830 & 27.9979 & 127.1427 & 17.0000 \\
\hline
\end{tabular}

Notes.(1) Cluster robust standard errors at firm level are in parentheses; (2) ${ }^{* * *} p<0.01,{ }^{* *} p<0.05,{ }^{*} p<0.1$ (two-sided test)

tends to have stronger influence on firm performance. Therefore, Hypothesis $4 \mathrm{c}$ is rejected.

\section{Robustness check}

We perform several robustness checks to verify the main results. In the interest of brevity, the results of all the robustness checks are not reported here, but are available upon request.

First, we use the PSM-DID approach for the robustness check. We estimate a Logit model year by year where the dependent variable is the binary treatment status variable Treat, and the regressors consist of all the control variables, including industry fixed 
Table 9 Influence of guanxi

\begin{tabular}{lllll}
\hline & $\mathbf{( 1 )}$ & $\mathbf{( 2 )}$ & $\mathbf{( 3 )}$ & $\mathbf{( 4 )}$ \\
& $\mathbf{R O A}$ & $\boldsymbol{R O E}$ & Tobin's $\mathbf{Q}$ & LEV \\
\hline TreatXPost & $0.0006(0.0018)$ & $0.0007(0.0035)$ & $-0.1484^{* * *}(0.0440)$ & $0.1172^{* * *}(0.0376)$ \\
Guanxi & $-0.0004(0.0075)$ & $0.0012(0.0174)$ & $-0.0249(0.1547)$ & $-0.0691(0.1440)$ \\
TreatXPostXGuanxi & $-0.0002(0.0008)$ & $-0.0011(0.0017)$ & $-0.0450^{* *}(0.0198)$ & $-0.0039(0.0189)$ \\
Control Variable & YES & YES & YES & YES \\
Firm fixed effect & YES & YES & YES & YES \\
Year fixed effect & YES & YES & YES & YES \\
$N$ & 18,942 & 18,798 & 18,026 & 17,444 \\
Adj_R $R^{2}$ & 0.0753 & 0.0594 & 0.3545 & 0.0365 \\
$F$ & 34.4928 & 27.6818 & 126.1402 & 16.6422 \\
\hline
\end{tabular}

Notes.(1) Cluster robust standard errors at firm level are in parentheses; (2) ${ }^{* * *} p<0.01,{ }^{* *} p<0.05,{ }^{*} p<0.1$ (two-sided test)

effect. We then append each year's PSM matched samples together to form a new panel data set, generated by the PSM algorithm. Based on the new panel data set, we perform balance tests to confirm whether the matching algorithm is successful. The results suggest that the $t$-values for all covariates are quite small after the PSM matching process, which supports the success of the matching process. We then use the PSM sample to run DID regressions as done in the main body tests, and achieve consistent findings, align to the baseline DID results.

Second, the announcements of the listed firms are used to identify the treatment group. When the OIDs resigned, the listed firms released public announcements that included the reasons for the resignations. In the robustness check, the treatment group is identified from the texts of the announcements using key phrases such as "according to Rule No. 18," "according to the new requirement" and "adopting the new rule." After re-defining the treatment group, the results are found to be robust and consistent with the baseline results.

Third, considering that some firms may not have OIDs during the years from 2010 to 2017 and the firms without OIDs may perform differently compared to those with OIDs, we exclude the firms without OIDs during the years from 2010 to 2017 from the control group. After re-defining the control group, we then run DID regressions as we did before and the results are again consistent with the baseline results.

Table 10 Influence of firm ownership

\begin{tabular}{|c|c|c|c|c|}
\hline & (1) & (2) & (3) & (4) \\
\hline & $R O A$ & ROE & Tobin's $Q$ & LEV \\
\hline Treat $\times$ Post & $0.0008(0.0024)$ & $0.0053(0.0046)$ & $0.1004(0.0614)$ & $0.0476(0.0443)$ \\
\hline Ownership & $-0.0136^{* *}(0.0055)$ & $-0.0234^{* *}(0.0110)$ & $-0.1014(0.1335)$ & $0.2845^{* *}(0.1322)$ \\
\hline Treat $\times$ Post $x$ Ownership & $-0.0003(0.0030)$ & $-0.0098(0.0061)$ & $-0.5183^{* * *}(0.0721)$ & $0.1395^{* *}(0.0667)$ \\
\hline Control variable & YES & YES & YES & YES \\
\hline Firm fixed effect & YES & YES & YES & YES \\
\hline Year fixed effect & YES & YES & YES & YES \\
\hline N & 18,942 & 18,798 & 18,026 & 17,444 \\
\hline $\operatorname{Adj} \_R^{2}$ & 0.0768 & 0.0606 & 0.3592 & 0.0384 \\
\hline F & 34.9520 & 28.1526 & 128.7995 & 17.0776 \\
\hline
\end{tabular}

Notes.(1) Cluster robust standard errors at firm level are in parentheses; (2) ${ }^{* *} p<0.01,{ }^{* *} p<0.05,{ }^{*} p<0.1$ (two-sided test) 
Lastly, considering that the effects of different tenure arrangements may be sensitive to the definition of tenure, we generate some binary variables to identify the tenures of OIDs by their mean and median values. To be specific, if the tenure is longer than the mean or median of the sample tenures, then AboveMean/AboveMedian equals 1; if the tenure is shorter than the mean or median of the sample tenures, then BelowMean/ BelowMedian equals 1, otherwise 0. We further interact these variables with Post. The results are consistent with those reported in Table 4, indicating that the effects of tenure are not sensitive to the definition of tenure.

\section{Supplementary examination}

Delay of OID resignations

In practice, mostly, there is a delay between an announcement of OID resignations and its actual departure from the board, because the firm needs some time to find and appoint replacements. Therefore, it is not uncommon that the OIDs still work as independent directors in the listed firms for some period of time, even though their resignations had been announced. For instance, some firms issued the OID resignation announcements in early 2014, but the OIDs remained in their positions until 2016. Hence, it is a reasonable assumption that those OIDs were still playing functional roles and influenced firm performance. As such, we generate a variable, Delay_Time, accounting for the time difference in months between the announcement and the actual departure, and test its effect on firm performance. Most OIDs actually left the listed firm within 12 months after the resignation announcement. We set up a group of binary variables to identify the delay situations and examine whether the delay time of OID resignations made a difference on the performance outcomes. The overall results suggest that, the longer an OID resignation is delayed, the more negative its effect on the firm.

\section{Potential channels through which OID resignations can affect firm performance}

We investigate the potential channels through which the OID resignations affect firm performance. Firstly, we explore whether the OID resignations have a negative effect on government subsidies by using the data from CSMAR and WIND databases. Considering that the value of government subsidies is larger than 0 , a Tobit model with year and industry fixed effects is used. We examine both the whole sample and the sub-samples divided into SOEs and non-SOEs separately. The results suggest that the OID resignations may result in firms, especially non-SOEs, receiving fewer government subsidies, which may further adversely impact firm performance.

Secondly, we explore whether the OID resignations have a negative effect on receiving preferential tax treatment. We consider that, when the OIDs resign, the probability of preferential tax treatment may decrease, which may lead to a negative effect on firm performance. In order to test the impact of losing preferential tax treatment, we collect the data of tax reimbursements for the listed firms from 2010 to 2017 from CSMAR and WIND databases as a proxy for whether the firm receives preferential tax treatment. A Logit model is used and the results indicate that the OID resignations reduce 
a firm's likelihood of receiving preferential tax treatment, and this may consequently affect firm performance in a negative way.

\section{Conclusion}

The implementation of Rule No. 18 provided a unique opportunity to study the effects of the independent directors' role on firm performance. Using an exogenous regulatory shock which mandated the sudden resignation of many OIDs in China, we provide empirical evidence of the effects of OID resignations and their heterogeneity on firm performance.

The overall findings show that Rule No. 18 had a significantly negative effect on firm performance as measured by Tobin's $Q$, and a significantly positive effect on raising firm risk as measured by $L E V$, indicating that the loss of OIDs has generally generated a negative shock on firm performance. However, the results also show that other measures, such as $R O E$ and $R O A$, do not suffer the apparent adverse shock, indicating that the importance of OIDs' political connections may not be as crucial to firm performance as initially thought.

Theoretically, we adopt the perspectives of RDT and SCT and further test the influence of OIDs' heterogeneity, including political hierarchy, tenure, serving status and professional background on firm performance. The results are largely consistent with what theories predict, thus extending the application of RDT and SCT to the examination of OIDs' political connections in China. More specifically, two aspects can be considered an extension of RDT and SCT. First, we find evidence to support the resourcing role of OIDs (Shi et al. 2018), addressing the examinations recorded in prior literature, which may be affected by the endogeneity problem (Agrawal and Knoeber 2001; Kim 2007). Although some researchers have used the sudden death of OIDs (Cheng 2018; Li and Cheng 2020) or their voluntary resignations (Dewally and Peck 2010) as a quasi-experimental setting, the results may be affected by the successors as well as the departing directors (Shi et al. 2018). Second, the prior literature mainly focuses on the resources or social capital brought by OIDs from a general perspective (Cheng and Sun 2019; Hu et al. 2020; Shi et al. 2018; Tang et al. 2016; Wang 2015; Wang et al. 2019; Zhu et al. 2016) without fully considering the heterogeneity of OIDs' backgrounds. We fill this gap by studying the heterogeneity of OIDs' backgrounds including their political hierarchy, tenure, serving status, professional and academic background, which provides further empirical evidence of the application of RDT and SCT in the OID context. In addition, we consider the external environment of the firm, including formal and informal institutions as measured by marketization and the culture of guanxi, respectively, and compare the effect between SOEs and non-SOEs. In general, we find that Rule No. 18 highlights the role that OIDs play on firm performance, which is largely positive, arguably due to the political connections that generate valuable resources for the firm. Therefore, losing OIDs in the short term is like losing a valuable asset to the firm.

Nonetheless, we also find that firms located in regions with higher levels of marketization and even non-SOEs suffer less from the short-term loss. Additionally, the profitability measures of firm performance also suffer less from OID resignations. These results indicate that political connections may not be necessary channels for firms to achieve success. 


\section{Acknowledgements}

No special acknowledgement.

\section{Authors' contributions}

All authors are listed according to contributions. The author(s) read and approved the final manuscript.

\section{Funding}

There is no funding to the study.

\section{Availability of data and materials}

Not applicable.

\section{Competing interests}

There is no competing interest.

\section{Author details}

${ }^{1}$ HSBC Business School, Peking University, Shenzhen, China. ${ }^{2}$ Department of Management, Lingnan University, Hong Kong, China. ${ }^{3}$ Highfund (Guangzhou) Equity Investment Fund, Guangzhou, China.

\section{Received: 18 February 2020 Accepted: 24 September 2020}

Published online: 28 October 2020

\section{References}

Adhikari, A., Derashid, C., \& Zhang, H. (2006). Public policy, political connections, and effective tax rates: Longitudinal evidence from Malaysia. Journal of Accounting and Public Policy, 25(5), 574-595.

Adler, P. S., \& Kwon, S. W. (2002). Social capital: Prospects for a new concept. Academy of Management Review, 27(1), 17-40.

Agrawal, A., \& Knoeber, C. R. (1996). Firm performance and mechanisms to control agency problems between managers and shareholders. Journal of Financial \& Quantitative Analysis, 31(3), 377-397.

Agrawal, A., \& Knoeber, C. R. (2001). Do some outside directors play a political role? The Journal of Law and Economics, 44(1), 179-198.

Boeker, W. B., \& Goodstein, J. (1991). Organizational performance and adaptation: Effects of environment and performance on changes in board composition. Academy of Management Journal, 34(4), 805-826.

Chen, D. H., \& Xiang, J. F. (2017). Is it reasonable for an independent director to be re-elected for six years? Evidence from China. Management World, 284(5), 144-157.

Chen, H., Hsu, W., \& Chang, C. (2016). Independent directors' human and social capital, firm internationalization and performance implications: An integrated agency-resource dependence view. International Business Review, 25(4), 859-871.

Cheng, L. (2018). Estimating the value of political connections in China: Evidence from sudden deaths of politically connected independent directors. Journal of Comparative Economics, 46(2), 495-514.

Cheng, L., \& Sun, Z. (2019). Do politically connected independent directors matter? Evidence from mandatory resignation events in China. China Economic Review, 58(C), Article 101188.

Chizema, A., Liu, X., Lu, J., \& Gao, L. (2015). Politically connected boards and top executive pay in Chinese listed firms. Strategic Management Journal, 36(6), 890-906.

Clarke, D. C. (2006). The independent director in Chinese corporate governance. Delaware Journal of Corporate Law, 31(1), $125-228$.

Dewally, M., \& Peck, S. W. (2010). Upheaval in the boardroom: Outside director public resignations, motivations, and consequences. Journal of Corporate Finance, 16(1), 38-52.

Dunn, M., Birley, S., \& Norburn, D. (1986). The marketing concept and the smaller firm. Marketing Intelligence \& Planning, 4(3), 3-11.

Dutton, J. E., Dukerich, J. M., \& Harquail, C. V. (1994). Organizational images and member identification. Administrative Science Quarterly, 39(2), 239-263.

Easterbrook, F. H. (1984). Managers' discretion and investors' welfare: Theories and evidence. Delaware Journal of Corporate Law, 9(3), 540-571.

Faccio, M. (2006). Politically connected firms. American Economic Review, 96(1), 369-386.

Faccio, M. (2010). Differences between politically connected and nonconnected firms: A cross-country analysis. Financial Management, 39(3), 905-928.

Faleye, O., Hoitash, R., \& Hoitash, U. (2011). The costs of intense board monitoring. Journal of Financial Economics, 101(1), 160-181.

Fan, J. P., Wong, T. J., \& Zhang, T. (2007). Politically connected CEOs, corporate governance, and post-IPO performance of China's newly partially privatized firms. Journal of Financial Economics, 84(2), 330-357.

Farashahi, M., \& Hafsi, T. (2009). Strategy of firms in unstable institutional environments. Asia Pacific Journal of Management, 26(4), 643-666.

Fisman, R. (2001). Estimating the value of political connections. American Economic Review, 91(4), 1095-1102.

Han, J., \& Zhang, G. (2018). Politically connected boards, value or cost: Evidence from a natural experiment in China. Accounting \& Finance, 58(1), 149-169.

Harris, M., \& Raviv, A. (2008). A theory of board control and size. The Review of Financial Studies, 21(4), 1797-1832.

He, K., Pan, X., \& Tian, G. G. (2017). Political connections, audit opinions, and auditor choice: Evidence from the ouster of government officers. Auditing: A Journal of Practice \& Theory, 36(3), 91-114.

Hermalin, B. E., \& Weisbach, M. S. (2001). Boards of directors as an endogenously determined institution: A survey of the economic literature. Federal Reserve Bank of New York Economic Policy Review, 9(Apr.), 7-26.

Hillman, A. J. (2005). Politicians on the board of directors: Do connections affect the bottom line? Journal of Management, 31(3), 464-481.

Hillman, A. J., Nicholson, G., \& Shropshire, C. (2008). Directors' multiple identities, identification, and board monitoring and resource provision. Organization Science, 19(3), 441-456. 
Hope, O. K., Yue, H., \& Zhong, Q. (2020). China's anti-corruption campaign and financial reporting quality. Contemporary Accounting Research, 37(2), 1015-1043.

Hou, Q., Hu, M., \& Yuan, Y. (2017). Corporate innovation and political connections in Chinese listed firms. Pacific-Basin Finance Journal, 46, 158-176.

Hu, R., Karim, K., Lin, K. J., \& Tan, J. (2020). Do investors want politically connected independent directors? Evidence from their forced resignations in China. Journal of Corporate Finance, 61, Article 101421.

Huang, H. H., \& Chan, C. Y. (2018). Firms' performance following the initial resignation of independent directors: Evidence from Taiwan. Asia Pacific Business Review, 24(5), 714-729.

Imbens, G. W. (2015). Matching methods in practice: Three examples. Journal of Human Resources, 50(2), 373-419.

Infante, L., \& Piazza, M. (2014). Political connections and preferential lending at local level: Some evidence from the Italian credit market. Journal of Corporate Finance, 29, 246-262.

Jensen, M. C.., \& Murphy, K. J. (1990). Performance pay and top-manager incentives. Journal of Political Economy, 98(2), 225-264. Jiang, F., \& Kim, K. A. (2015). Corporate governance in China: A modern perspective. Journal of Corporate Finance, 32(3), 190-216.

Jiang, W., Wan, H., \& Zhao, S. (2016). Reputation concerns of independent directors: Evidence from individual director voting. The Review of Financial Studies, 29(3), 655-696.

Johnson, S., \& Mitton, T. (2003). Cronyism and capital controls: Evidence from Malaysia. Journal of Financial Economics, 67(2), $351-382$.

Keim, G. D., \& Zeithaml, C. P. (1986). Corporate political strategy and legislative decision making: A review and contingency approach. Academy of Management Review, 11(4), 828-843.

Kim, Y. (2007). The proportion and social capital of outside directors and their impacts on firm value: Evidence from Korea. Corporate Governance: An International Review, 15(6), 1168-1176.

Kor, Y. Y., \& Sundaramurthy, C. (2009). Experience-based human capital and social capital of outside directors. Journal of Management, 35(4), 981-1006.

Krishnan, G. V., Raman, K. K., Yang, K., \& Yu, W. (2011). CFO/CEO-board social ties, Sarbanes-Oxley, and earnings management. Accounting Horizons, 25(3), 537-557.

Lefort, F., \& Urzúa, F. (2008). Board independence, firm performance and ownership concentration: Evidence from Chile. Journal of Business Research, 61(6), 615-622.

Lester, R. H., Hillman, A., Zardkoohi, A., \& Cannella Jr., A. A. (2008). Former government officials as outside directors: The role of human and social capital. Academy of Management Journal, 51(5), 999-1013.

Li, H., Meng, L., Wang, Q., \& Zhou, L. (2008). Political connections, financing and firm performance: Evidence from Chinese private firms. Journal of Development Economics, 87(2), 283-299.

Li, Z., \& Cheng, L. (2020). What do private firms do after losing political capital? Evidence from China. Journal of Corporate Finance, 60, 101551.

Lin, K., Piotroski, J. D., Yang, Y. G., \& Tan, J. (2012). Voice or exit? Independent director decisions in an emerging economy. SSRN Working Paper.

Liu, Q., Tang, J., \& Tian, G. G. (2013). Does political capital create value in the IPO market? Evidence from China. Journal of Corporate Finance, 23, 395-413.

Liu, Y., Miletkov, M. K., Wei, Z., \& Yang, T. (2015). Board independence and firm performance in China. Journal of Corporate Finance, 30(1), 223-244.

Luo, Y., \& Chen, M. (1997). Does guanxi influence firm performance? Asia Pacific Journal of Management, 14(1), 1-16.

Nguyen, B. D., \& Nielsen, K. M. (2010). The value of independent directors: Evidence from sudden deaths. Journal of Financial Economics, 98(3), 550-567.

Peng, M. W. (2004). Outside directors and firm performance during institutional transitions. Strategic Management Journal, 25(5), 453-471.

Peng, M. W., \& Heath, P. S. (1996). The growth of the firm in planned economies in transition: Institutions, organizations, and strategic choice. Academy of Management Review, 21(2), 492-528.

Pfeffer, J., \& Salancik, G. R. (1978). The external control of organizations: A resource dependence perspective. New York: Harper and Row.

Puffer, S. M., McCarthy, D. J., \& Boisot, M. (2010). Entrepreneurship in Russia and China: The impact of formal institutional voids. Entrepreneurship Theory and Practice, 34(3), 441-467.

Qin, X., \& Zhang, X. (2019). De-politicization and innovation: Evidence from China. Journal of Accounting and Public Policy, 38(4), Article 106668.

Quan, Y., \& Li, S. (2017). Are academic independent directors punished more severely when they engage in violations? China Journal of Accounting Research, 10(1), 71-86.

Reguera-Alvarado, N., \& Bravo, F. (2017). The effect of independent directors' characteristics on firm performance: Tenure and multiple directorships. Research in International Business \& Finance, 41, 590-599.

Shi, H., Xu, H., \& Zhang, X. (2018). Do politically connected independent directors create or destroy value? Journal of Business Research, 83, 82-96.

Shin, R. W., \& Ha, Y.S. (1999). Political economy of policy reform in Korea: Review and analysis. Review of Policy Research, 16(2), 65-98.

Shivdasani, A., \& Yermack, D. (1999). CEO involvement in the selection of new board members: An empirical analysis. The Journal of Finance, 54(5), 1829-1853.

Tang, X., Lin, Y., Peng, Q., Du, J., \& Chan, K. C. (2016). Politically connected directors and firm value: Evidence from forced resignations in China. The North American Journal of Economics and Finance, 37, 148-167.

Tian, J., Haleblian, J., \& Rajagopalan, N. (2011). The effects of board human and social capital on investor reactions to new CEO selection. Strategic Management Journal, 32(7), 731-747.

Wang, C., Xie, F., \& Zhu, M. (2015). Industry expertise of independent directors and board monitoring. Journal of Financial and Quantitative Analysis, 50(5), 929-962.

Wang, L. (2015). Protection or expropriation: Politically connected independent directors in China. Journal of Banking \& Finance, 55, 92-106.

Wang, L., \& Lin, P. T. (2017). Who benefits from political connections? Minority investors or controlling shareholders. AsiaPacific Journal of Accounting \& Economics, 24(1-2), 1-22. 
Wang, X., Fan, G., \& Hu, L. P. (2018). Marketization index of China's province: NERI report 2018. Beijing: Social Sciences Academic Press.

Wang, X., Feng, M., \& Xu, X. (2019). Political connections of independent directors and firm internationalization: An empirical study of Chinese listed firms. Pacific-Basin Finance Journal, 58, 101205.

Wei, C., Hu, S., \& Chen, F. (2020). Do political connection disruptions increase labor costs in a government-dominated market? Evidence from publicly listed companies in China. Journal of Corporate Finance, 62, 101554.

Weisbach, M. S. (1988). Outside directors and CEO turnover. Journal of Financial Economics, 20, 431-460.

$\mathrm{Xu}, \mathrm{Y}$. (2018). Anticorruption regulation and firm value: Evidence from a shock of mandated resignation of directors in China. Journal of Banking \& Finance, 92, 67-80.

Ye, W., Li, X., Zhu, H., \& Liu, L. (2016). Informal institution: The guanxi index construction and measurement. Quarterly Journal of Management, Z1, 73-91.

Zhang, M., Liu, Y., Xie, L., \& Ye, T. (2017). Does the cutoff of "red capital" raise a red flag? Political connections and stock price crash risk. The North American Journal of Economics and Finance, 39, 89-109.

Zhu, J., Ye, K., Tucker, J. W., \& Chan, K. J. C. (2016). Board hierarchy, independent directors, and firm value: Evidence from China. Journal of Corporate Finance, 41, 262-279.

\section{Publisher's Note}

Springer Nature remains neutral with regard to jurisdictional claims in published maps and institutional affiliations.

Submit your manuscript to a SpringerOpen ${ }^{\odot}$ journal and benefit from:

- Convenient online submission

- Rigorous peer review

- Open access: articles freely available online

- High visibility within the field

- Retaining the copyright to your article

Submit your next manuscript at $\boldsymbol{\nabla}$ springeropen.com 